\title{
Development of polyclonal antibodies against nucleocapsid protein of watermelon silver mottle virus and their application to diagnostic
}

\author{
Z. WU, W. WANG, Y. LI, X. RAO*
}

\begin{abstract}
Laboratory of Plant Virology, College of Natural Resources and Environment, South China Agricultural University, Guangzhou, 510642, P. R. China
\end{abstract}

Received September 25, 2013; accepted May 20, 2014

\begin{abstract}
Summary. - Watermelon silver mottle virus (WSMoV) is an emerging disease of cucurbit crops in South China. Production of high-quality antibodies is necessary for the development of serological methods for detection of this virus. The nucleocapsid protein (NP) gene of WSMoV was amplified from WSMoV-infected watermelon leaves by RT-PCR and cloned into vector pET-28a (+) for prokaryotic expression. After identification via enzyme digestion and sequencing, the recombinant clone was transformed into Escherichia coli Rosetta (DE3) for protein expression. Sodium dodecyl sulfate polyacrylamide gel electrophoresis (SDS-PAGE) results showed that the molecular weight of the WSMoV NP fusion protein was $34.1 \mathrm{kDa}$. The fusion protein was purified and used as antigen for the preparation of polyclonal antisera in rabbits. Results of indirect ELISA and western blot analysis showed that the antisera reacted specifically with WSMoV NP. In addition, sensitivity and specificity of the antisera were examined on a number of infected field samples by indirect ELISA. These findings will facilitate further immunological and serological studies of WSMoV.
\end{abstract}

Keywords: watermelon silver mottle virus; polyclonal antibody; western blot; prokaryotic expression

\section{Introduction}

Watermelon (Citrullus lanatus) is a major cucurbitaceous crop in China with 180 million hectare under plantation in 2011. The demand for watermelons is bound to increase with adjustment of the structure of agricultural production and improvement of people's living standards. However, plant viruses cause significant reductions in watermelon yield (Wang et al., 2013). WSMoV is a newly reported tospovirus infecting watermelons in South China (Rao et al., 2011). The main classification criteria of tospoviruses are the nucleocapsid protein (NP) gene and its deduced amino acid sequence,

"Corresponding author. E-mail: raoxq@hotmail.com; fax: 086020-85281107.

Abbreviations: $\mathrm{CaCV}=$ capsicum chlorosis virus; $\mathrm{CMV}=$ cucumber mosaic virus; HCRV = hippeastrum chlorotic ringspot virus; IPTG = Isopropyl $-\beta$-D-thiogalactopyranoside; $\mathrm{NP}=$ nucleocapsid protein; sodium $\mathrm{WSMoV}=$ watermelon silver mottle virus serological relationship, and biological characteristics such as thrips vector species and host range (de Avila et al., 1993; Dewey et al., 1996). Based on serological relationship of NPs, current classification of tospoviruses consists of three related serogroups including iris yellow spot virus, tomato spotted wilt virus and watermelon silver mottle virus (WSMoV) and four distinct serotypes including impatiens necrotic spot virus, panut yellow spot virus, peanut chlorotic fan-spot virus, and melon yellow spot virus (Yeh and Chang, 1995; Chu et al., 2001; Lin et al., 2005; Pappu et al., 2009; Chen et al., 2010; Seepiban et al., 2011). In addition, several new tospovirus species, such as alstroemeria necrotic streak virus, tomato necrotic ringspot virus, soybean vein necrosis-associated virus, bean necrotic mosaic virus, and hippeastrum chlorotic ringspot virus (HCRV) have been identified recently (Hassani-Mehraban et al., 2010; Seepiban et al., 2011; Zhou et al., 2011; de Oliveira et al., 2012; Dong et al., 2013).

WSMoV consists of one negative-sense large (L) RNA and two ambisense medium (M) and small (S) single-stranded 
RNAs (Rao et al., 2013). The L RNA encodes the RNAdependent RNA polymerase necessary for virus replication, whereas the $\mathrm{M}$ and S RNAs encode a nonstructural protein important for the cell-to-cell movement and the NSs protein for the silencing suppressor in the viral sense strand, as well as the membrane glycoproteins Gn/Gc and NP in the viral complementary strand (de Haan et al., 1990; Kormelink et al., 1992, 1994; Takeda et al., 2002).

Antibodies against NPs of tospoviruses are commonly used for diagnosis and identification of tospoviruses. Previous studies showed that the titer of polyclonal and monoclonal antibodies against WSMoV obtained after immunization with purified nucleocapsids using virus-infected lesion hosts were high (Yeh et al., 1996; Lin et al., 2005), but the titer of some commercial antisera against WSMoV NP in China was too low for satisfactory diagnosis. Thus, a high quality polyclonal antibody against WSMoV NP is urgently needed to accurately diagnose WSMoV.

This study demonstrates the expression of WSMoV NP in E. coli, production of polyclonal antibodies against WSMoV NP using recombinant protein as antigen, and the suitability of these antibodies for ELISA and western blot immunodiagnosis. The preparation of a polyclonal antibody should facilitate further functional studies of WSMoV.

\section{Materials and Methods}

RT-PCR, cloning, and sequencing. Total genomic RNA was extracted from WSMoV-GZ-infected watermelon leaves collected from greenhouses in the suburb of Zengcheng City in Guangdong Province using RNAprep pure kit (May Gene, China) and following the manufacturer's protocol. These samples were diagnosed through double antibody sandwich ELISA (DAS-ELISA) and RT-PCR as described previously (Rao et al., 2011). The NP gene was amplified by RT-PCR, using primer pairs MeiWS-NF (5'-GGATCCATGTCTAACGTTAAGCAGC-3', BamHI restriction site in bold, corresponding to nucleotide sequences 3520-3538 of S RNA from WSMoV-GZ isolate) and MeiWS-NR (5'-GTCGACGGTTGACACTTCAAAGTTACAC-3', SalI restriction site in bold, corresponding to nucleotide sequences 2695-2716 of SRNA from WSMoV-GZ isolate). RT-PCR was performed using the following program in a Takara PCR thermal cycler (Japan): cDNA synthesis at $50^{\circ} \mathrm{C}$ for $30 \mathrm{~min}$ followed by $95^{\circ} \mathrm{C}$ for $5 \mathrm{~min}$; 35 cycles of $95^{\circ} \mathrm{C}$ for $30 \mathrm{sec}, 50^{\circ} \mathrm{C}$ for $30 \mathrm{sec}$, and $72^{\circ} \mathrm{C}$ for $45 \mathrm{sec}$; $10 \mathrm{~min}$ final extension at $72^{\circ} \mathrm{C}$. The amplified products were purified using a Gel Extraction Kit (Biotech, Guangzhou, China) and cloned in pMD18-T vector (Takara, Dalian, China), then the recombinant $\mathrm{pMD} 18$-T-NP plasmid verified by PCR and sequenced by the automated model 3730 DNA sequencing system (Aoke, Guangzhou, China).

Expression and purification of the fusion protein. The recombinant pMD18-T-NP plasmid was digested with BamHI and
SalI (Takara, Dalian, China), and the NP target sequence was subcloned into sites digested by the same endonucleases in the pET28a (+) vector (Novagen). The recombinant plasmid designated as pET28a-NP was transformed into E. coli Rosetta (DE3). The transformed bacteria were grown on LB plates with $50 \mu \mathrm{g} / \mathrm{ml}$ kanamycin and confirmed by restriction enzyme digestion and sequencing. A single colony of positive bacteria was cultivated at $37^{\circ} \mathrm{C}$ in $\mathrm{LB}$ medium with $50 \mu \mathrm{g} / \mathrm{ml}$ kanamycin until an optical density (OD600) of 0.6 was reached. The fusion protein was induced by adding Isopropyl- $\beta$-D-thiogalactopyranoside (IPTG) to a final concentration of $0.6 \mathrm{mmol} / \mathrm{l}$ for $4 \mathrm{hr}$ at $37^{\circ} \mathrm{C}$. The $E$. coli Rosetta (DE3) cells were harvested at $4^{\circ} \mathrm{C}$ by centrifugation at $10,000 \times \mathrm{g}$ for $10 \mathrm{~min}$. The pellets were suspended in Tris-buffered saline (50 mmol/l NaCl, $20 \mathrm{mmol} / \mathrm{l}$ Tris- $\mathrm{HCl}, \mathrm{pH}$ 7.9) containing $5 \mathrm{mmol} / \mathrm{l}$ imidazole and $6 \mathrm{~mol} / \mathrm{l}$ urea, and the inclusion bodies were completely lysed by sonication on ice (Ultrasonic processor JY92-II ). The lysate was centrifuged at 13,000 $\times$ g for $30 \mathrm{~min}$ to separate unlysed cells from the lysate, the supernatant was filtered through a $0.45 \mu \mathrm{m}$ membrane and then purified using a Clontech HisTALON ${ }^{\mathrm{TM}}$ purified protein kit (Takara, Dalian, China) following the manufacturer's instructions. The loaded column was extensively washed with washing buffer $(20 \mathrm{mmol} / \mathrm{l}$ $\mathrm{Na}_{2} \mathrm{HPO}_{4}, 500 \mathrm{mmol} / \mathrm{l} \mathrm{NaCl}$, and $6 \mathrm{~mol} / \mathrm{l}$ urea) containing 100 $\mathrm{mmol} / \mathrm{l}$ imidazole. The purification efficiency of the target fusion protein was determined by $12 \%$ SDS-PAGE. The gel was stained with Coomassie brilliant blue R-250 for over $1 \mathrm{hr}$ and destained in $10 \%$ acetic acid until the protein band was clear. Uninduced transformed E. coli were used as controls.

Preparation of polyclonal antibodies against the NP. The purified fusion proteins were used for producing antibodies in two New Zealand rabbits. Briefly, $200 \mu \mathrm{g} / \mathrm{ml}$ of purified fusion protein was mixed with an equal volume of Freund's complete adjuvant (Whiga, Guangzhou, China) and injected into rabbits via subcutaneous injection. One week later, $250 \mu \mathrm{g} /$ $\mathrm{ml}$ purified fusion protein with Freund's incomplete adjuvant (Whiga, Guangzhou, China) was injected. The immunization was repeated four times at the interval of 7 days. Seven days after the last injection, antisera were harvested and stored at $-80^{\circ} \mathrm{C}$ for further use.

Assessment of antibody production. Indirect ELISA was used to estimate the titer and the specificity of antisera as described previously (Rao et al., 2005). The dilutions of polyclonal antisera ranged from 1:100 to $1: 4,800$. The crude extracts from WSMoV-GZ-infected watermelon leaves $(1: 10 \mathrm{w} / \mathrm{v})$ and healthy watermelon leaves $(1: 10 \mathrm{w} / \mathrm{v})$ were used as the antigen and negative control, respectively. Each sample was tested in duplicates. Samples were considered positive when absorbance at $492 \mathrm{~nm}$ was at least twice the average value of the negative control. The ELISA results of field survey were confirmed by RT-PCR using primer pairs WS-NF and WS-NR (the sequences of WS-NF and WS-NR were the same as MeiWS-NF and MeiWS-NR, but no BamHI and SalI). The product was $844 \mathrm{bp}$ long and contained the complete NP open reading frame (ORF). 
The specificity of the produced antisera was evaluated for their reaction with WSMoV by indirect ELISA. Cucumber mosaic virus (CMV), capsicum chlorosis virus (CaCV), and HCRV were used for comparison. Crude extracts from healthy tobacco leaves (1:10 $\mathrm{w} / \mathrm{v}$ ) were used as negative control.

Western-blot assay. Western blot analysis was performed as previously described (Towbin et al., 1979). The purified NP fusion proteins were used to examine the immunoreactivity of rabbit antisera.

\section{Results}

\section{Construction and expression of the fusion protein}

A predicted 856 bp product containing the complete NP ORF was amplified from WSMoV-GZ-infected watermelon leaves by RT-PCR. The sequence analysis showed that the NP genes of the WSMoV-GZ isolate (GenBank Acc. No. JX177645) shared $92.1 \%$ to $92.8 \%$ nucleotide identity and $96.7 \%$ to $97.5 \%$ amino acid identity with the WSMoV isolates WSMoVTospo-W (NC_003843), WSMoV-WS-Y (AB042650), WSMoV (Z46419), and WSMoV-KB (FR695062). These results confirmed that the sequence contains a full-length WSMoVGZ NP gene. Restriction endonuclease analysis of pET28a-NP and subsequent sequencing revealed that the NP gene was inserted in-frame with intact $\mathrm{N}$-end tags.

After the recombinant plasmid containing the NP gene was transformed into host cells, IPTG was used to induce the

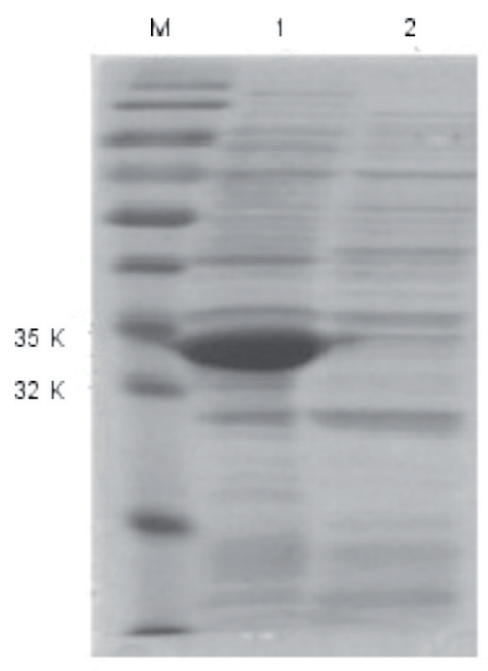

Fig. 1

SDS-PAGE analysis of the His-tagged WSMoV NP fusion protein after sonication

The His-tagged fusion NP of WSMoV (lane 1), the supernatants of transformed E. coli lysate (lane 2), protein size marker (lane M). expression of the fusion protein. SDS-PAGE analysis showed that a His-tagged fusion protein $(6 \times \mathrm{His})$ with approximate molecular weight of $34.1 \mathrm{kDa}$ was expressed as expected (Fig. 1). After purifying through a Ni-NTA column using imidazole, the fusion target protein with one distinct band of $34.1 \mathrm{kDa}$ was obtained and subsequently confirmed by western blotting with anti-His tag (Roche, Switzerland) (Fig. 2a) and anti-WSMoV NP antibodies (provided by professor Yeh SD) (Fig. 2b). Our results demonstrate that the fusion protein harboring the WSMoV NP with His-tag was successfully expressed.

\section{Assessment of antibody production}

The specificity and sensitivity of the polyclonal antisera developed against the NP of WSMoV were evaluated for their specific reaction with WSMoV-infected plant tissues by western blot and indirect ELISA.

Western blot results showed that the produced antiserum $(1: 2,000)$ reacted strongly with the WSMoV NP fusion protein with approximate molecular weight of $34.1 \mathrm{kDa}$, whereas no reactive band was observed in uninduced of the transformed E. coli Rosetta (DE3) (Fig. 3).

Indirect ELISA results indicated that the antiserum allowed for the detection of WSMoV-infected watermelon leaves in dilutions ranging from 1:100 to 1:3,200, with an initial mean absorbance at $492 \mathrm{~nm}$ ranging from 0.295 (1:100) to $0.067(1: 3,200)$, and 0.029 for the negative control, and that the absorbance value of WSMoV-infected watermelon leaves was more than twice that of the negative control (Fig. 4).

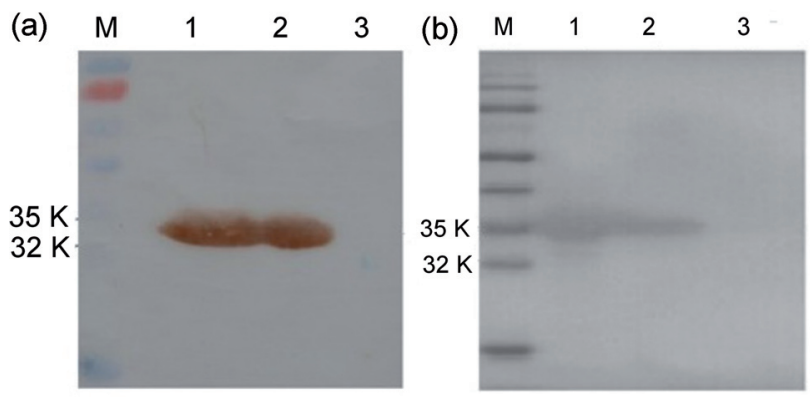

Fig. 2

Western blot analysis of His-tagged fusion NP expressed in E. coli Rosetta (DE3)

(a). Western blot analysis of His-tagged fusion NP with His-Tag rabbit antibody. Expression of His-tagged fusion NP from the recombinant plasmid pET28a-NP induced by IPTG (lanes 1-2); uninduced transformed E. coli (lane 3), protein size marker (lane M). (b). Western blot analysis of Histagged fusion NP with antibody against WSMoV NP (provided by professor Yeh SD). Expression of His-tagged fusion NP of recombinant plasmid pET28a-NP induced by IPTG (lanes 1-2), uninduced transformed E. coli (lane 3), protein size marker (lane M). 


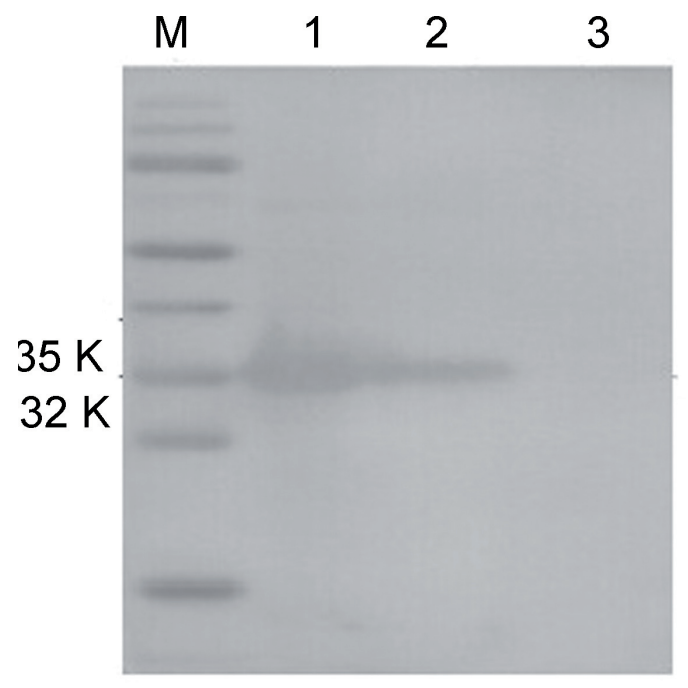

Fig. 3

Western blot analysis of fusion WSMoV NP with the produced polyclonal antibody at 1:2,000 dilution

Expression of His-tagged fusion NP from the recombinant plasmid pET28aNP induced by IPTG (lane 1), purified fusion WSMoV NP (lane 2), uninduced transformed E. coli (lane 3), protein size marker (lane M).

The indirect ELISA detection of other viruses showed that the mean absorbance values at $492 \mathrm{~nm}$ were 0.042 (CMV), 0.028 (CaCV), 0.053 (HCRV), and 0.087 (WSMoV), whereas the mean absorbance of the negative control of tobacco was 0.039. Thus, the mean absorbance values of $\mathrm{CMV}, \mathrm{CaCV}$, and HCRV were less than twice that of the negative control, while that of WSMoV was more than two-fold the value of the negative control. Our results showed that $\mathrm{CMV}, \mathrm{CaCV}$, and HCRV were negative, and the antibodies were specific for WSMoV.

\author{
Detection of WSMoV from diseased watermelon with \\ antisera
}

To determine whether the antisera reacted with the diseased watermelon samples collected from the fields, 51 extracts of diseased samples from infected watermelon plants were subjected to indirect ELISA by using the crude antiserum at the dilution of 1:2,000. The mean OD492 values for crude sap were in the range of 0.084-0.622 for diseased watermelon samples and 0.018 for crude sap from healthy plants (data not shown). The absorbance values of infected samples were more than twice that of the healthy sample. All of the 51 samples reacted positively with the antisera against WSMoV NP. The 51 positive samples were also confirmed by RT-PCR (data not shown) and they were all positive.

\section{Discussion}

In this study, we report a successful expression of WSMoV NP fusion protein in E. coli and utilization of purified fusion protein and field samples to test the reactivity of the polyclonal antisera developed against WSMoV NP. NP is an important functional protein and a major criterion for the classification of tospoviruses (Goldbach and Kuo, 1996; Chen et al., 2005). Antisera against NPs are usually utilized for diagnosis and identification of tospoviruses (Yeh et al., 1996; Ghotbi et al., 2005; Lin et al., 2005; Chen et al., 2010). Our results demonstrate that anti- WSMoV NP antibody can recognize and react specifically with WSMoV in indirect ELISA. Moreover, the titer of the polyclonal antibody against WSMoV NP was 1:3,200, which satisfies the requirement of a commercial antiserum against WSMoV. Thus, the produced

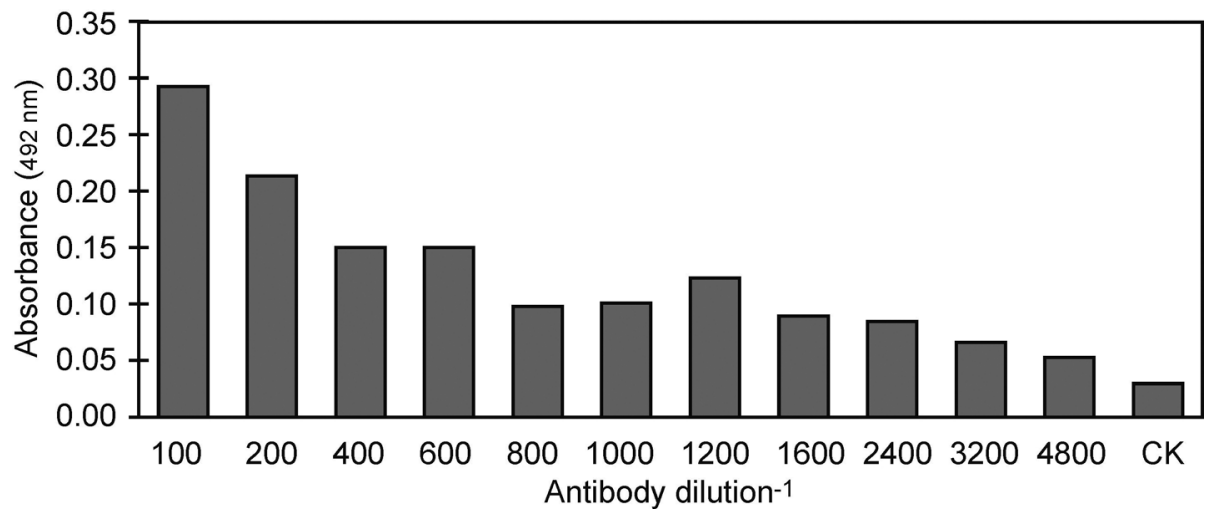

Fig. 4

The titer of the produced polyclonal antibodies against WSMoV NP was tested using indirect ELISA CK was the absorbance value of the negative control. The crude extract of an uninfected watermelon (1:10 w/v) was used as the negative control. $\mathrm{x}$-axis: antibody dilution; $y$-axis: absorbance at $492 \mathrm{~nm}$. 
polyclonal antibody was reliable and specific for the detection of WSMoV.

The antibodies of tospovirus are usually produced using purified virus or NP as immunogens. Several methods have been reported to prepare tospoviral NPs as immunogens, such as purification of tospoviruses or nucleocapsids directly from virus-infected plant tissues, expression of NP using a plant viral vector in planta or use of prokaryotic expression systems (Yeh et al., 1996; Chu et al., 2001; Chen et al., 2005; Jain et al., 2005; Lin et al., 2005; Wu et al., 2009; Khatabi et al., 2012). Among these, expression of fusion proteins in E. coli is the most advantageous, as it lends itself to easy tospovirus protein purification and ease of manipulation, and the background values caused by contamination of plant proteins can be neglected (Elliott et al., 1996). This approach has been successfully applied to produce antisera for detection of several other plant viruses (Sugiyama et al., 1995; Jain et al., 2005; Lee and Chang, 2008). Our results show that the purified expressed protein is a good immunogen for producing specific polyclonal antibodies in inoculated rabbits. The resulting polyclonal antiserum against NP can also be successfully applied for efficient detection of field samples infected by WSMoV. However, not all antibodies raised against recombinant antigens are generally functional when used with non-denatured materials (plant extracts) (Jelkmann and Keim-Konrad, 1997; Nickel et al., 2004). Although WSMoV is an enveloped quasi-spherical particle, the produced polyclonal antibodies are still effective at recognizing the virus by indirect ELISA. Thus, the utilization of the WSMoV NP fusion protein as an antigen for immunization in rabbits provides an effective alternative for difficult purification of viruses from infected plants.

WSMoV is one of the main limited factors for growing cucurbitaceous crops in infested areas (Heinze et al., 1995; Yeh and Chang, 1995; Okuda et al., 2001; Peng et al., 2011), and controlling WSMoV remains a significant challenge. Therefore, developing a sensitive, rapid, and specific diagnostic method for field samples is necessary. In this study, we expressed and purified recombinant WSMoV NP and obtained specific polyclonal antisera against WSMoV. These specific polyclonal antibodies should be highly valuable for developing reliable diagnostic assays for WSMoV infected crops.

Acknowledgements. The authors would like to thank professor Yeh SD (Department of Plant Pathology, National Chung Hsing University, Taiwan) for kindly providing antiserum against WSMoV NP. This work was supported by Guangdong Provincial Science and Technology Projects, China (Grant No. 2012B020309003).

\section{References}

Chen TC, Hsu HT, Jain RK, Huang CW, Lin CH, Liu FL, Yeh SD (2005): Purification and serological analyses of tospoviral nucleocapsid proteins expressed by Zucchini yellow mosaic virus vector in squash. J. Virol. Methods 129, 113124. http://dx.doi.org/10.1016/j.jviromet.2005.05.014

Chen TC, Lu YY, Cheng YH, Li JT, Yeh YC, Kang YC, Chang CP, Huang LH, Peng JC, Yeh SD (2010): Serological relationship between Melon yellow spot virus and Watermelon silver mottle virus and differential detection of the two viruses in cucurbits. Arch. Virol. 155, 1085-1095. http:// dx.doi.org/10.1007/s00705-010-0688-y

Chu FH, Chao CH, Peng YC, Lin SS, Chen CC, Yeh SD (2001): Serological and molecular characterization of Peanut chlorotic fan-spot virus, a new species of the genus Tospovirus. Phytopathology 91, 856-863. http://dx.doi. org/10.1094/PHYTO.2001.91.9.856

de Avila AC, de Haan P, Kormelink R, Resende RdeO, Goldbach RW, Peters D (1993): Classification of tospoviruses based on the phylogeny of nucleoprotein gene sequences. J. Gen. Virol. 74, 153-159. http://dx.doi.org/10.1099/0022$\underline{1317-74-2-153}$

de Haan P, Wagemakers L, Peters D, Goldbach R (1990): The S RNA segment of Tomato spotted wilt virus has an ambisense character. J. Gen. Virol. 71, 1001-1007. http://dx.doi. org/10.1099/0022-1317-71-5-1001

de Oliveira AS, Melo FL, Inoue-Nagata AK, Nagata T, Kitajima EW, Resende Re O (2012): Characterization of Bean necrotic mosaic virus: A member of a novel evolutionary lineage within the genus Tospovirus. Plos One 7(6), e38634. http://dx.doi.org/10.1371/journal.pone.0038634

Dewey RA, Semorile LC, Crici JV, Grau O (1996): Clustering of Argetinean tospoviruses with existing species in the genus by sequence analysis of a 450-nucleotide RNA region of the N gene. Virus Genes 13, 255-262. http://dx.doi. org/10.1007/BF00366986

Dong JH, Yin YY, Fang Q, Mcbeath JH, Zhang ZK (2013): A new tospovirus causing chlorotic ringspot on Hippeastrum sp. in China. Virus Genes 46, 567-570. http://dx.doi. org/10.1007/s11262-012-0873-Z

Elliott MS, Zettler FW, Zimmerman MT, Barnett OWJr, Legrande MD (1996): Problems with interpretation of serological assays in a virus survey of orchid species from Puerto Rico, Ecuador, and Florida. Plant Dis. 80, 1160-1164. http://dx.doi.org/10.1094/PD-80-1160

Goldbach R, Kuo G (1996): Introduction: Proceedings of the international symposium on tospovirus and thrips of floral and vegetable crops. Acta Hortic. 431, 21-26.

Ghotbi T, Shahraeen N, Winter S (2005): Occurrence of tospoviruses in ornamental and weed species in Markazi and Tehran provinces in Iran. Plant Dis. 89, 425-429. http:// dx.doi.org/10.1094/PD-89-0425

Hassani-Mehraban A, Botermans M, Verhoeven JT, Meekers E, Saaijer J, Peters D, Goldbach R, Kormelink R (2010): A distinct tospovirus causing necrotic streak on Alstro- 
emeria sp. In Colombia. Arch. Virol. 155, 423-428. http:// dx.doi.org/10.1007/s00705-010-0590-7

Heinze C, Maiss E, Adam G, Casper R (1995): The complete nucleotide sequence of the S RNA of a new tospovirus species, representing serogroup IV. Phytopathology 85 , 683-690. http://dx.doi.org/10.1094/Phyto-85-683

Jain RK, Pandey AN, Krishnareddy M, Mandal B (2005): Immunodiagnosis of groundnut and watermelon bud necrosis viruses using polyclonal antiserum to recombinant nucleocapsid protein of Groundnut bud necrosis virus. J. Virol. Methods 130, 162-164. http://dx.doi.org/10.1016/j. jviromet.2005.06.018

Jelkmann W, Keim-Konrad R (1997): Immuno-capture polymerase chain reaction and plate-trapped ELISA for the detection of Apple stem pitting virus. J. Phytopathol. 145, 499-503. http://dx.doi.org/10.1111/j.1439-0434.1997.tb00357.x

Khatabi B, Wen RH, Hershman DE, Kennedy BS, Newman MA, Hajimorad MR (2012): Generation of polyclonal antibodies and serological analyses of nucleocapsid protein of Soybean vein necrosis-associated virus: A distinct soybean infecting tospovirus serotype. Eur. J. Plant Pathol. 133, 783-790. http://dx.doi.org/10.1007/s10658012-9969-5

Kormelink R, de Haan P, Meurs C, Peters D, Goldbach R (1992): The nucleotide sequence of the M RNA segment of Tomato spotted wilt virus, a bunyavirus with two ambisense RNA segments. J. Gen. Virol. 73, 2795-2804. http://dx.doi. org/10.1099/0022-1317-73-11-2795

Kormelink R, Storms M, van Lent J, Peters D, Goldbach R (1994): Expression and subcellular location of the NSm protein of Tomato spotted wilt virus (TSWV), a putative viral movement protein. Virol. 200, 56-65. http://dx.doi. org/10.1006/viro.1994.1162

Lee SC, Chang YC (2008): Performances and application of antisera produced by recombinant capsid proteins of Cymbidium mosaic virus and Odontoglossum ringspot virus. Eur. J. Plant Pathol. 122, 297-306. http://dx.doi.org/10.1007/ s10658-008-9293-2

Lin YH, Chen TC, Hsu HT, Liu FL, Chu FH, Chen CC, Lin YZ, Yeh SD (2005): Serological comparison and molecular characterization for verification of Calla lily chlorotic spot virus as a new tospovirus species belonging to Watermelon silver mottle virus serogroup. Phytopathology 95, 1482-1488. http://dx.doi.org/10.1094/PHYTO-95-1482

Nickel O, Targon MLPN, Fajardo TVM, Machado MA, Trivilin AP (2004): Polyclonal antibodies to the coat protein of Apple stem grooving virus expressed in Escherichia coli: production and use in immunodiagnosis. Fitopatol. Bras. 29, 558-562. http://dx.doi.org/10.1590/S010041582004000500017

Okuda M, Taba S, Tsuda S, Hidaka S, Kameya-Iwaki M, Hanada K (2001): Comparison of the S RNA segments among Japanese isolates and Taiwanese isolates of Watermelon silver mottle virus. Arch. Virol. 146, 389-394. http:// dx.doi.org/10.1007/s007050170183

Pappu HR, Jones RA, Jain RK (2009): Global status of tospovirus epidemics in diverse cropping systems: Successes achieved and challenges ahead. Virus Res. 141, 219-236. http://dx.doi.org/10.1016/j.virusres.2009.01.009

Peng JC, Yeh SD, Huang LH, Li JT, Cheng YF, Chen TC (2011): Emerging threat of thrips-borne Melon yellow spot virus on melon and watermelon in Taiwan. Eur. J. Plant Pathol. 130, 205-214. http://dx.doi.org/10.1007/s10658011-9746-x

Rao X, Zhang S, Gao Q (2005): Detecting viruses in banana differentiated shoots from tissue culture. J. South China Agricultural University 26, 64-66.

Rao X, Liu Y, Wu Z, Li Y (2011): First report of natural infection of watermelon by Watermelon silver mottle virus in China. New disease reports 24,12 . http://dx.doi.org/10.5197/ j.2044-0588.2011.024.012

Rao X, Wu Z, Li Y (2013): Complete genome sequence of a Watermelon silver mottle virus isolate from China. Virus Genes 46, 576-580. http://dx.doi.org/10.1007/s11262$\underline{013-0885-3}$

Seepiban C, Gajanandana O, Attathom T, Attathom S (2011): Tomato necrotic ringspot virus, a new tospovirus isolated in Thailand. Arch. Virol. 156, 263-274. http://dx.doi. org/10.1007/s00705-010-0856-0

Sugiyama Y, Hamamoto H, Takemoto S, Watanabe Y, Okada Y (1995): Systemic production of foreign peptides on the particle surface of Tobacco mosaic virus. FEBS Lett. 359, 247-250. http://dx.doi.org/10.1016/0014-5793(95)00054-D

Takeda A, Sugiyama K, Nagano H, Mori M, Kaido M, Mise K, Tsuda S, Okuno T (2002): Identification of a novel RNA silencing suppressor, NSs protein of Tomato spotted wilt virus. FEBS Lett. 532, 75-79. http://dx.doi.org/10.1016/ $\underline{\text { S0014-5793(02)03632-3 }}$

Towbin H, Staehelin T, Gordon J (1979): Electrophoretic transfer of proteins from polyacrylamide gels to nitrocellulose sheets: procedure and some applications. Proc. Natl. Acad. Sci. USA 76, 4350-4354. http://dx.doi.org/10.1073/ pnas.76.9.4350

Wang C, Zhang L, Zhao J, Wu J (2013): Analysis of China's watermelon market and its future prospect. Agricultural Outlook 4, 27-30.

Wu J, Yu C, Yang C, Zhou X (2009): Monoclonal antibodies against the recombinant nucleocapsid protein of Tomato spotted wilt virus and its application in virus detection. J. Phytopath. 157, 344-349. http://dx.doi.org/10.1111/j.14390434.2008.01498.x

Yeh SD, Chang TF (1995): Nucleotide sequence of the N gene of Watermelon silver mottle virus, a proposed new member of the genus Tospovirus. Phytopathology 85, 58-64. http://dx.doi.org/10.1094/Phyto-85-58

Yeh SD, Chao CH, Cheng YH, Chen CC (1996): Serological comparison of four distinct tospoviruses by polyclonal antibodies to purified nucleocapsid proteins. Acta Hortic. $431,122-134$

Zhou J, Kantartzi SK, Wen RH, Newman M, Hajimorad MR, Rupe JC, Tzanetakis IE (2011): Molecular characterization of a new tospovirus infecting soybean. Virus Genes 43, 289-295. http://dx.doi.org/10.1007/s11262-011-0621-9 